\title{
Comparison of DNA and protein synthesis rates of bacterial assemblages between coral reef waters and pelagic waters in tropical ocean
}

\author{
I. Yoshinaga ${ }^{1}$, K. Fukami ${ }^{2}$, Y. Ishida ${ }^{1}$ \\ ${ }^{1}$ Department of Fisheries, Faculty of Agriculture, Kyoto University, Kyoto 606, Japan \\ ${ }^{2}$ Department of Cultural Fisheries, Faculty of Agrículture, Kochi University, Kochi 783, Japan
}

\begin{abstract}
DNA and protein synthesis activities of Pacific bacterial assemblages in coral reefs of Ponape Island (eutrophic water), Majero Atoll (mesotrophic water) and pelagic waters (oligotrophic water) were estimated by measuring incorporation rates of ${ }^{3} \mathrm{H}$-thymidine and ${ }^{3} \mathrm{H}$-leucine into the TCAinsoluble fraction ( $T d R_{D N A}$, Leuprol $)$. Bacterial production rates estimated by $T d R_{D N A}$ were 0.14 to 0.94 (average 0.52 ) $\times 10^{4}$ cells ml $\mathrm{ml}^{-1} \mathrm{~h}^{-1}$ in the pelagic water and 0.93 to 26 (average 10 ) $\times 10^{4} \mathrm{cells} \mathrm{ml}^{-1} \mathrm{~h}^{-1}$ in the eutrophic water Obligate oligotrophs predominated in the pelagic water, but facultative oligotrophs were dominant in the eutrophic water. In the eutrophic water protein synthesis rates expressed by Leu $u_{\text {prot }}$ were positively correlated to DNA synthesis rates expressed by TdR DNA; however, in the oligotrophic pelagic water, there was no such correlation. Uptake activities of leucine at low concentration were maintained at relatively high levels in the oligotrophic water although ${ }^{3} \mathrm{H}$-thymidine incorporation rates were extremely low. From these results, it is suggested that bacterial assemblages in oligotrophic waters have an uptake system with high affinity to substrates and utilize metabolic energy to achieve substrate uptake and protein synthesis preferentially to DNA synthesis and reproduction, and that these properties were mostly due to obligately oligotrophic bacteria adapted to a low nutrient environment.
\end{abstract}

\section{INTRODUCTION}

Many reports have shown that most marine pelagic bacteria adapt to oligotrophic environments and prefer lower nutrient conditions (less than $10 \mathrm{mgC}^{-1}$ ) to higher nutrient conditions (Carlucci \& Shimp 1976, Akagi et al. 1977, Ishida et al. 1986). Oligotrophic bacteria can tentatively be divided into 2 groups: obligate oligotrophs and facultative oligotrophs (Ishida et al. 1980, 1986). The latter authors define obligate oligotrophs as bacteria that can grow in a low nutrient medium $\left(0.5\right.$ to $\left.5 \mathrm{mgC}^{-1}\right)$ but not in a high nutrient medium, such as ZoBell 2216E. Facultative oligotrophs can grow in a relatively wide range of nutrient concentration. Previous results, using the ${ }^{14} \mathrm{C}-\mathrm{MPN}$ method (Ishida et al. 1986, Eguchi \& Ishida 1990), indicated that obligate oligotrophs were predominant in pelagic oceans with extremely low nutrient concentrations. On the other hand, in eutrophic coastal waters facultative oligotrophs and/or eutrophs which can grow in a high nutrient medium were dominant. These results led us to believe that heterotrophic bacterial assemblages in oligotrophic pelagic waters must possess different physiological properties from those of bacteria in eutrophic waters, with regard to the capability of effective nutrient uptake at low concentrations, and low maintenance energy and growth.

Recently, many studies on bacterial production have revealed that a large soluble fraction derived from primary production is utilized by heterotrophic bacteria in marine ecosystems and converted into bacterial biomass (Ducklow \& Kirchman 1983, Ducklow et al. 1986, Cole et al. 1988, Hagström et al. 1988, Rosenberg et al. 1990). Bacterial production rates were generally estimated by using a ${ }^{3} \mathrm{H}$-thymidine method (Fuhrman \& Azam 1982). Azam \& Fuhrman (1984) summarized that thymidine incorporation has already yielded useful estimates of bacterial production in seawater. Several problems, however, have arisen. Establishing conversion factors from thymidine incorporation rates to bacterial production rates is one of the most serious. Moreover it is possible that the conversion factor could be variable depending on bacterial physiological conditions as well as community structure. 
Kirchman et al. (1985) proposed that the rate of protein synthesis estimated from radiolabeled leucine incorporation into the hot trichloroacetic acid (hotTCA) insoluble fraction may be a more direct measure of heterotrophic activity in aquatic environments (Chin-Leo \& Kirchman 1988, Kirchman \& Hoch 1988 , Kirchman et al. 1989). A simultaneous application of leucine and thymidine methods is particularly useful in elucidating the physiological dynamics of bacterial assemblages in marine environments.

In this paper, we report on determinations of bacterial production rates in eutrophic waters over tropical coral reefs and in oligotrophic waters in the pelagic ocean, and attempt to clarify the physiological differences in DNA and protein synthesis activities between oligotrophic and eutrophic bacterial assemblages. Subsequently, we discuss the physiological properties of oligotrophic bacterial assemblages: how these assemblages utilize a limited nutrient and energy source to maintain their heterotrophic activities.

\section{MATERIALS AND METHODS}

Sampling sites. Water samples were collected during the KH-88-1 cruise of RV 'Hakuho-maru' (Ocean Research Institute, University of Tokyo) in March 1988. The sampling area in the $W$ Pacific Ocean is illustrated in Fig. 1A, B, C. At Majero Atoll, 3 water samples were taken at Stn MA, which was situated just on the coral reef, 2 (MA1 and MA3) during ebb tide and 1 (MA2) during flood tide. Stations at Ponape Island were on the reef fringe. Water samples at Stns PA through PG were collected during ebb tide on 14 March (PA1) and 15 March (all other stations).

Surface waters were collected using sterile glass bottles which were precombusted at $450^{\circ} \mathrm{C}$ for $1.5 \mathrm{~h}$ for removal of any organic contamination. At $\operatorname{Stn} 28$, which was situated in a pelagic area with a water depth of $1860 \mathrm{~m}$, water samples were collected from $0,10,20,30$ and $50 \mathrm{~m}$ depths. Deeper water samples were taken with a rosette multisampler. These water samples were stored at $5^{\circ} \mathrm{C}$ until they were used in the experiments.

DOC determination. Each water sample was filtered with a glass fiber filter (Whatman, GF/F) combusted at $450^{\circ} \mathrm{C}$ for $1.5 \mathrm{~h}$. Dissolved organic carbon (DOC) concentrations in filtrates were measured with a TOC meter (Shimadzu, TOC-500) after pretreatment with concentrated $\mathrm{HCl}$.

Incorporation rates of ${ }^{3} \mathrm{H}$-thymidine and ${ }^{3} \mathrm{H}$-leucine. We investigated incorporation rates of ${ }^{3} \mathrm{H}$-thymidine into the cold-TCA insoluble fraction ( $\left.T d R_{D N A}\right)$ and of ${ }^{3} \mathrm{H}$-leucine into the hot-TCA insoluble fraction (Leuprot) for estimation of DNA and protein synthesis rates. Triplicate water samples of $20 \mathrm{ml}$ for pelagic waters
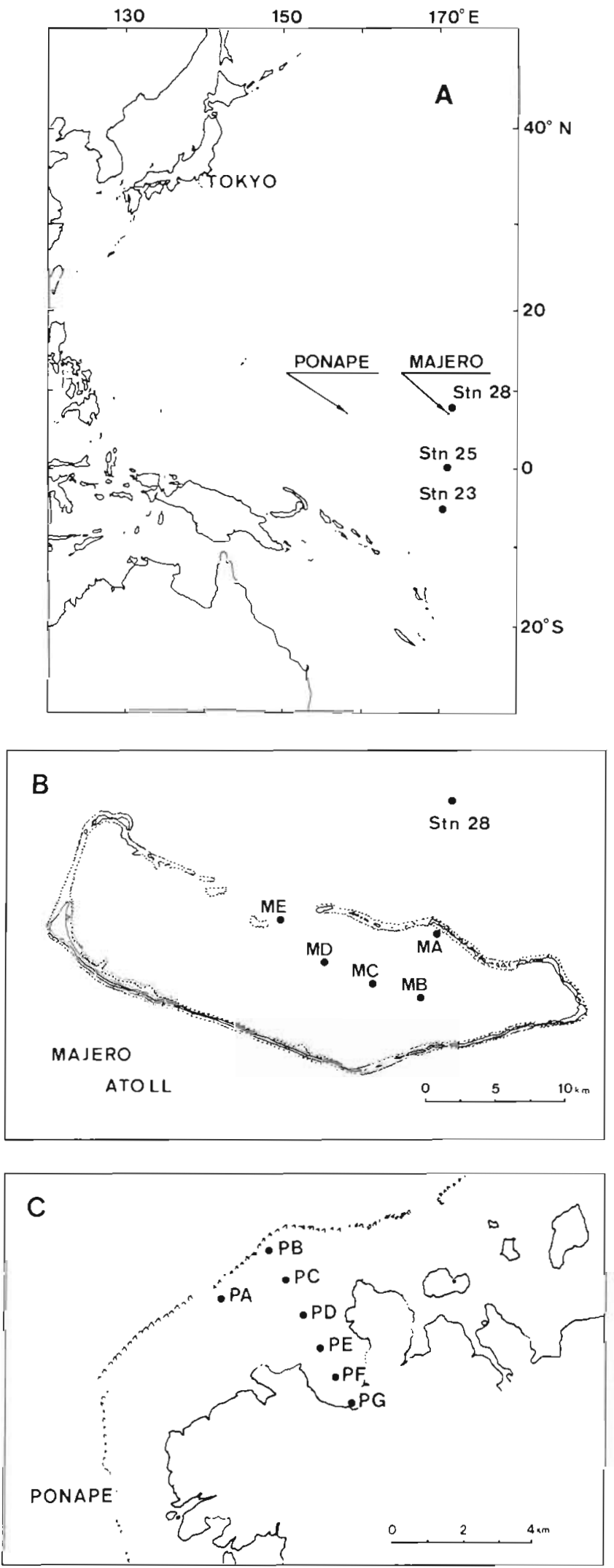

Fig. 1. Location of sampling stations in (A) the Pacific Ocean, (B) Majero Atoll and (C) Ponape Island 
and $10 \mathrm{ml}$ for near-shore water were incubated with either $5 \mathrm{nM}$ methyl- ${ }^{3} \mathrm{H}$-thymidine $\left(56 \mathrm{Ci} \mathrm{mmol}^{-1}, \mathrm{CEA}\right)$ or $5 \mathrm{nM} \mathrm{L-}{ }^{3} \mathrm{H}$-leucine $\left(120 \mathrm{Ci} \mathrm{mmol}{ }^{-1}, \mathrm{CEA}\right)$ at in situ temperature. After $1 \mathrm{~h}$ incubation, the reaction was stopped by adding ice-cold TCA $15 \%$ of final concentration). Samples for $T d R_{D N A}$ were cooled on ice for 5 min to extract a macromolecular fraction. Samples for Leu $u_{\text {prot }}$ were heated for $1 \mathrm{~h}$ at $80^{\circ} \mathrm{C}$ to hydrolyze all macromolecules except proteins. The insoluble fraction of each sample was collected onto a membrane filter (pore size, $0.2 \mu \mathrm{m}$ ), rinsed with $10 \mathrm{ml}$ of $5 \%$ ice-cold TCA twice, and then transferred into a glass vial containing $5 \mathrm{ml}$ of scintillation cocktail (Aquasol 2). Incorporated radioactivities were measured with a liquid scintillation counter (Aloka LSC502). In order to estimate a bacterial production rate, ${ }^{3} \mathrm{H}$-thymidine incorporation rates $\left(T d R_{D N A}\right)$ were multiplied by $1.7 \times 10^{18}$ cells mol $^{-1}$ thymidine (Fuhrman \& Azam 1982).

To examine the total assimilation rate of leucine into whole cell materials, Leuass, water samples were incubated with $5 \mathrm{nM}{ }^{3} \mathrm{H}$-leucine in the same manner as described above. After incubation, bacterial cells were collected on membrane filters as quickly as possible without TCA treatment, rinsed with cold filtered seawater twice, and then their radioactivities were determined. Radioactivities of formalin-killed water samples ( $2 \%$ final concentration) were measured for abiotic adsorption of radioactivity.

Bacterial counting. Total bacterial abundance was measured with epifluorescence microscopy after DAPI staining (Porter \& Feig 1980). The number of viable oligotrophic bacteria was counted by the modified Ishida's MPN method (Ishida \& Kadota 1979, Ishida et al. 1980). Water samples were diluted appropriately and samples of each dilution step were inoculated into 5 replicate test tubes containing $3 \mathrm{ml}$ of ST $10^{-4}$ medium, which included $0.5 \mathrm{mg}$ trypticase peptone (BBL) and $0.05 \mathrm{mg}$ yeast extract (Difco) in 11 of aged seawater (ASW). After 1 mo incubation at $25^{\circ} \mathrm{C}$, we detected bacterial growth in each tube by direct observation under an epifluorescence microscope, and the most probable number (MPN) was determined from a series of numbers for bacterial growth-positive tubes. These bacterial numbers are regarded as values for total oligotrophic bacteria (TO), which are able to grow in a low nutrient medium like ST $10^{-4}$ medium. In addition, a part of a culture in each tube was inoculated secondarily into freshly prepared ST10-1 medium, which contained 1000-fold higher nutrient concentrations than ST10 ${ }^{-4}$. After 2 wk incubation, bacterial growth was detected by turbidity in each tube and an MPN value again obtained. The MPN values from the secondary inoculum were regarded as those of facultative oligotrophs (FO), which could grow in both low $\left(\mathrm{ST} 10^{-4}\right)$ and high $\left(\mathrm{ST} 10^{-1}\right)$ nutrient media.

\section{RESULTS}

Numbers of bacteria of several categories, DOC and chlorophyll a concentrations at each sampling point are presented in Table 1. DOC concentrations in surface waters of the inlet of Majero Atoll (Stns MD and ME) and those in pelagic waters were around $1 \mathrm{mgC}^{-1}$ or less. However, DOC concentrations in the inner atoll (Stns MB and MC) and on the coral reef (Stn MA) at Majero, and at all sampling points at Ponape, were generally more than $2 \mathrm{mgC}^{-1}$. DOC concentrations, chlorophyll a concentrations and total bacterial numbers (DAPI-DC) in coral reef waters of Ponape and Majero were higher than those at the inlet of Majero Atoll and in pelagic waters (Table 1). Although the chlorophyll a concentration was notably low at Stn PG, the innermost point at Ponape, the DOC concentration was high $\left(4.65 \mathrm{mgC}^{-1}\right)$, resulting from the location of station just beside the shore where many pollutants were present.

MPN counts of total oligotrophs (TO) in pelagic waters were generally lower $\left(0.3\right.$ to $2.3 \times 10^{3}$ cells $\mathrm{ml}^{-1}$ ) than those at Majero and Ponape (Table 1). At Majero and Ponape, on the other hand, facultative oligotrophs (FO), which could grow in both high and low nutrient media, often predominated. In pelagic waters, the percentages of obligate oligotrophs to total oligotrophs, calculated as $(1-\mathrm{FO} / \mathrm{TO}) \times 100$, were usually more than $80 \%$ with one exception (10 $\mathrm{m}$ depth of Stn 28; Table 1).

A vertical profile of bacterial production rates at Stn 28 and horizontal profiles of those in Majero and Ponape derived from ${ }^{3} \mathrm{H}$-thymidine incorporation rates into cold-TCA insoluble fraction ( $\left.\mathrm{TdR}_{\mathrm{DNA}}\right)$ are presented in Figs. $2 \& 3 \mathrm{~A}, \mathrm{~B}$. Bacterial production rates in pelagic waters and at the inlet of Majero Atoll were estimated to be at most $10^{4}$ cells $\mathrm{ml}^{-1} \mathrm{~h}^{-1}$. The horizontal profile of bacterial production at Ponape (Fig. 3B) shows variations from $9.3 \times 10^{3}$ cells $\mathrm{ml}^{-1} \mathrm{~h}^{-1}$ at Stn PA1 to $2.6 \times$ $10^{5}$ cells $\mathrm{ml}^{-1} \mathrm{~h}^{-1}$ at Stn PG. Bacterial production rates showed a statistically significant positive correlation to DOC concentrations $\left(\mathrm{r}^{2}=0.67, \mathrm{p}<0.01\right)$.

The correlation between $\mathrm{TdR}_{\mathrm{DNA}}$ and leucine incorporation rates into the hot-TCA insoluble fraction $\left(\right.$ Leu $\left._{\text {prot }}\right)$ is shown in Fig. 4. TdR DNA of bacterial assemblages in eutrophic water, such as Ponape water, was positively correlated to $L e u_{\text {prot }}$. When values of $T d R_{D N A}$ were lower than $10^{-14} \mathrm{~mol} \mathrm{mi}^{-1} \mathrm{~h}^{-1}$ in Majero and pelagic waters, values of Leu prot remained nearly constant, at around a few $10^{-14} \mathrm{~mol} \mathrm{ml^{-1 }} \mathrm{h}^{-1}$, although $\mathrm{TdR}_{\mathrm{DNA}}$ fluctuated significantly.

Total amounts of leucine assimilated into whole cell materials ( Leu $_{\text {ass }}$ ) (see 'Materials and methods') were measured at Stn 28 and in Majero waters. In Fig. 5A $\mathrm{TdR}_{\mathrm{DNA}}$ is plotted against Leu ass and in Fig. 5B against 
Table 1. Bacterial profiles, chlorophyll a concentrations and DOC concentrations in pelagic water, Majero Atoll and Ponape water. TO: number of total oligotrophs counted by MPN method with ST10 ${ }^{-4}$ medium; FO: number of facultative oligotrophs; OO/FO: percentage of obligate oligotrophs $(O O),(1-$ FO/TO $\times 100$; DAPI-DC: total bacterial number counted by direct counting method with DAPI stain; DOC: dissolved organic carbon concentration; chl a: chlorophyll a concentration from 'Preliminary Report of The Hakuho Maru Cruise KH-88-1'. ND: no data

\begin{tabular}{|c|c|c|c|c|c|c|c|}
\hline Station & $\begin{array}{l}\text { Depth } \\
\text { (m) }\end{array}$ & $\begin{array}{c}\mathrm{TO} \\
\text { (cells } \mathrm{ml}^{-1} \text { ) }\end{array}$ & $\begin{array}{c}\mathrm{FO} \\
\text { (cells } \mathrm{ml}^{-1} \text { ) }\end{array}$ & $\begin{array}{c}\text { OOTOO } \\
(\%)\end{array}$ & $\begin{array}{l}\text { DAPI-DC } \\
\left.\text { (cell } \mathrm{ml}^{-1}\right)\end{array}$ & $\begin{array}{c}\text { DOC } \\
\left({\left.\operatorname{ugC~} 1^{-1}\right)}^{-1}\right.\end{array}$ & $\begin{array}{c}\text { Chl } a \\
\left(\mu \mathrm{gl}^{-1}\right)\end{array}$ \\
\hline \multicolumn{8}{|c|}{ Pelagic water } \\
\hline \multirow{5}{*}{ Stn 28} & 0 & $2.3 \times 10^{3}$ & $2.3 \times 10^{2}$ & 90.0 & $8.3 \times 10^{5}$ & 0.86 & 0.06 \\
\hline & 10 & $1.7 \times 10^{3}$ & $1.3 \times 10^{3}$ & 23.5 & $1.3 \times 10^{6}$ & 1.71 & 0.06 \\
\hline & 20 & $3.3 \times 10^{2}$ & $2.3 \times 10$ & 93.0 & $8.6 \times 10^{5}$ & 1.34 & 0.05 \\
\hline & 30 & $1.3 \times 10^{3}$ & $2.3 \times 10^{2}$ & 82.3 & $6.2 \times 10^{5}$ & 1.36 & 0.06 \\
\hline & 50 & $4.6 \times 10^{2}$ & $2.3 \times 10$ & 95.0 & $8.3 \times 10^{5}$ & 1.24 & 0.06 \\
\hline Stn 23 & 0 & $1.3 \times 10^{3}$ & $1.7 \times 10^{2}$ & 86.9 & $8.4 \times 10^{5}$ & 1.02 & $N D$ \\
\hline Stn 25 & 0 & $7.9 \times 10^{2}$ & $1.3 \times 10^{2}$ & 83.5 & $8.1 \times 10^{5}$ & 0.96 & ND \\
\hline \multicolumn{8}{|l|}{ Majero } \\
\hline MA1 & 0 & $4.9 \times 10^{3}$ & $2.3 \times 10^{3}$ & 53.1 & $9.5 \times 10^{5}$ & 2.16 & ND \\
\hline $\mathrm{MA} 2$ & 0 & $1.7 \times 10^{4}$ & $1.3 \times 10^{4}$ & 23.5 & $1.4 \times 10^{6}$ & 2.25 & ND \\
\hline MA3 & 0 & $2.3 \times 10^{3}$ & $2.3 \times 10^{3}$ & 0.0 & $9.7 \times 10^{5}$ & 2.15 & ND \\
\hline $\mathrm{MB}$ & 0 & $4.9 \times 10^{3}$ & $4.9 \times 10^{3}$ & 0.0 & $1.2 \times 10^{6}$ & 2.09 & ND \\
\hline $\mathrm{MC}$ & 0 & $1.7 \times 10^{4}$ & $7.0 \times 10^{3}$ & 58.8 & $1.1 \times 10^{6}$ & 2.08 & ND \\
\hline $\mathrm{MD}$ & 0 & $2.3 \times 10^{3}$ & $7.9 \times 10^{2}$ & 65.7 & $8.0 \times 10^{5}$ & 0.82 & ND \\
\hline $\mathrm{ME}$ & 0 & $7.9 \times 10^{3}$ & $1.3 \times 10^{3}$ & 83.5 & $1.0 \times 10^{5}$ & 0.64 & ND \\
\hline \multicolumn{8}{|l|}{ Ponape } \\
\hline PA1 & 0 & $1.2 \times 10^{4}$ & $2.2 \times 10^{3}$ & 81.7 & $1.1 \times 10^{6}$ & 1.66 & ND \\
\hline PA2 & 0 & $7.9 \times 10^{3}$ & $3.3 \times 10^{3}$ & 58.2 & $7.8 \times 10^{5}$ & 1.95 & ND \\
\hline PB & 0 & $2.3 \times 10^{3}$ & $1.7 \times 10^{3}$ & 26.1 & $8.8 \times 10^{5}$ & 2.74 & 0.10 \\
\hline $\mathrm{PC}$ & 0 & $7.0 \times 10^{2}$ & $4.6 \times 10^{2}$ & 34.3 & $1.0 \times 10^{6}$ & 1.95 & 0.32 \\
\hline $\mathrm{PD}$ & 0 & $4.9 \times 10^{3}$ & $4.9 \times 10^{3}$ & 0.0 & $1.6 \times 10^{6}$ & 2.17 & 0.39 \\
\hline $\mathrm{PE}$ & 0 & $2.2 \times 10^{3}$ & $1.7 \times 10^{3}$ & 22.7 & $1.1 \times 10^{6}$ & 2.04 & 0.27 \\
\hline $\mathrm{PF}$ & 0 & $4.6 \times 10^{3}$ & $1.8 \times 10^{3}$ & 60.9 & $1.3 \times 10^{6}$ & 4.26 & 0.57 \\
\hline$P G$ & 0 & $1.4 \times 10^{4}$ & $1.1 \times 10^{3}$ & 92.1 & $1.1 \times 10^{6}$ & 4.65 & 0.06 \\
\hline
\end{tabular}

percentage of Leuprot to Leu ass. Leu ass of the bacterial assemblages at 3 depths $(20,30$ and $50 \mathrm{~m})$ at $\operatorname{Stn} 28$ and at 1 station at Majero (Stn ME) were significantly higher than those in more eutrophic waters (Stns MA, $\mathrm{MB}, \mathrm{MC}$ and $\mathrm{MD}$ ), although DOC concentrations were low, and consequently, bacterial production rates estimated by $\mathrm{TdR}_{\mathrm{DNA}}$ were low (Fig. 3A). The latter resulted in only 42.5 to $68.6 \%$ of leucine taken up into bacterial cells being incorporated into the protein fraction in these areas, while bacterial assemblages of other stations and depths incorporated nearly all the leucine into the protein fraction. Leucine uptake activities of the 3 surface water samples in the pelagic area were also high, and percentages of Leuprot to Leuass were between 34.3 and $59.4 \%$ (mean value $50.7 \%$ ) (data not shown).

\section{DISCUSSION}

As bacterial assemblages in the pelagic ocean are usually exposed to extremely low nutrient environments, some scientists have believed that most bacteria must be gradually starving to death or have already died (Morita 1985). However, using the microautoradiographic method, Douglas et al. (1987) showed that a large part of the total bacteria in natural environments assimilated radiolabeled glutamate (>50\%)

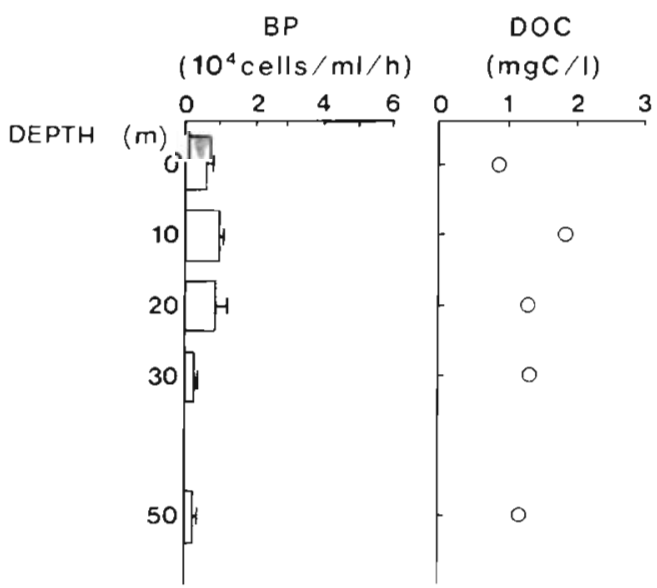

Fig. 2. Vertical profiles of bacterial productions (BP) and dissolved organic carbon (DOC) concentrations at Stn 28 

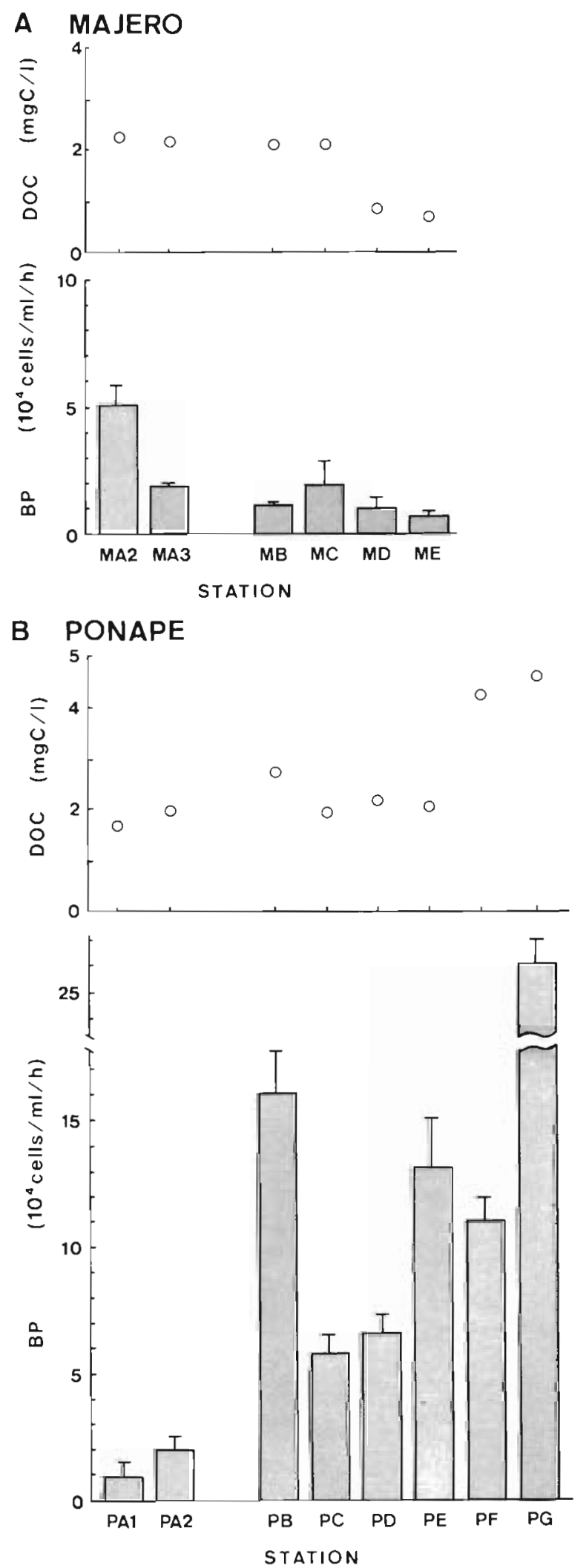

Fig. 3. Horizontal profiles of bacterial production (BP) and DOC concentrations at (A) Majero and (B) Ponape. MA2 and MA3 samples were collected at 11:40 h (ebb) and 15:00 h (flood) respectively on 5 March 1988 at Stn MA. PA1 and PA2 samples were collected on 14 and 15 March respectively at Stn PA

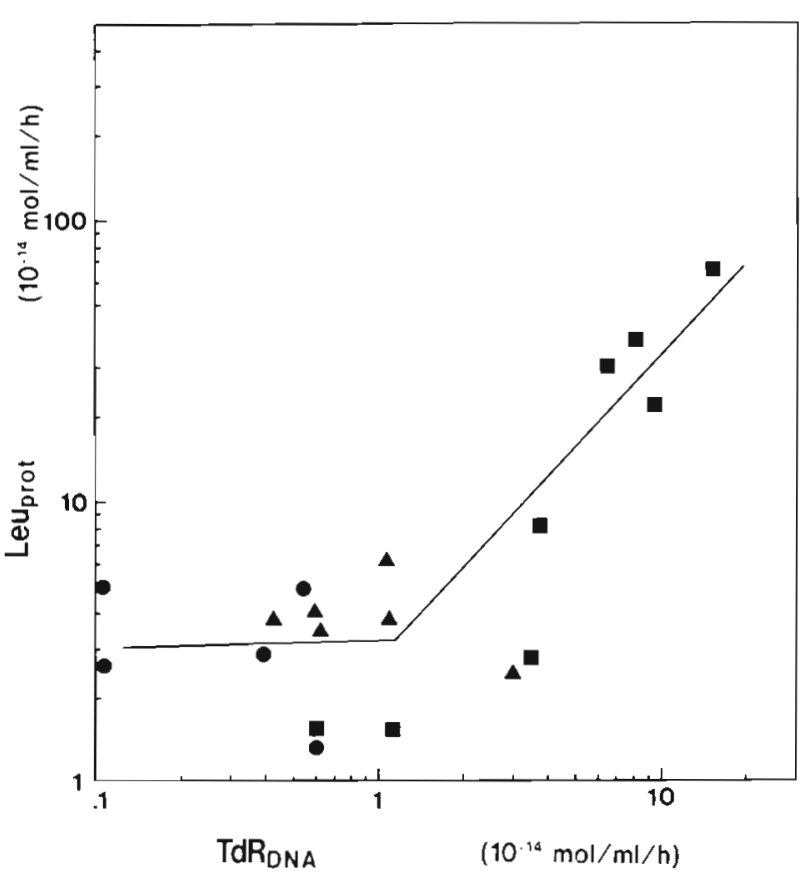

Fig. 4. Overall relationship between ${ }^{3} \mathrm{H}$-thymidine incorporation rates $\left(T d R_{D N A}\right)$ and ${ }^{3} \mathrm{H}$-leucine incorporation rates

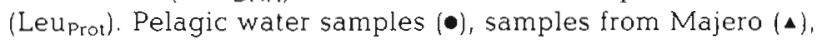
and samples from Ponape ( $\bullet$ ) were plotted

and thymidine $(>10 \%)$. A recent study using the thymidine methad also revealed that bacterial production in oligotrophic Mediterranean Sea water required $60 \%$ of primary production (Hagström et al. 1988). These results support the recognition that most bacteria are not dead or dying, but metabolically active, even in oligotrophic environments.

In the present study, average DOC concentrations and total bacterial numbers (DAPI-DC) in pelagic

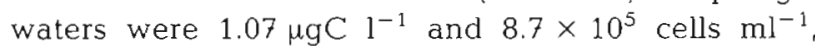
respectively, and were generally lower than those in the coral reef waters of Majero and Ponape where average DOC and DAPI-DC were high (Table 1). Viable bacterial abundances counted by the MPN method with a low nutrient medium (total oligotrophic bacteria, TO) were higher than those counted with high nutrient agar plates, and most bacteria (> $82.3 \%$ ) in the pelagic waters, except for those in water from $10 \mathrm{~m}$ depth at Stn 28, were obligate oligotrophs (OO) (Table 1). This result confirms a previous proposition (Ishida et al. 1986) that obligate oligotrophs were dominant in oligotrophic pelagic oceans and played the most significant role among microbial communities. In the coral reef waters of Majero and Ponape, on the other hand, since DOC concentrations were higher, TO were more abundant than in pelagic water with higher percentages of facultative oligotrophs (FO) (Table 1). Coral reef waters in Ponape and Majero seemed to be eutrophic areas.

Bacterial production rates of pelagic water ranged 


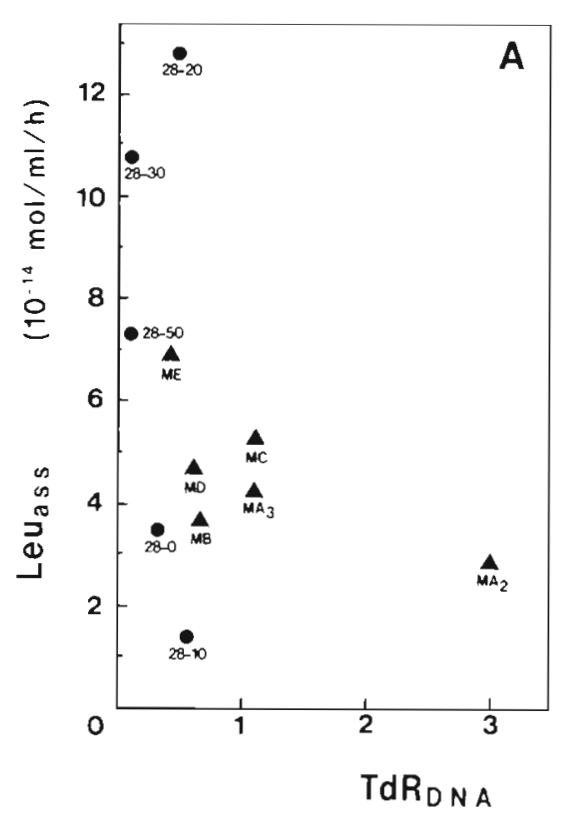

from 0.14 to 0.94 (average 0.52 ) $\times 10^{4}$ cells $\mathrm{ml}^{-1} \mathrm{~h}^{-1}$ and those of fringing reef waters in Ponape were 0.93 to 26 (average 10$) \times 10^{4}$ cells $\mathrm{ml}^{-1} \mathrm{~h}^{-1}$, i.e. 1 or 2 orders of magnitude higher (Figs. 2 \& 3B). From the inner area (Stns MA, MB and MC) to the inlet (Stns MD and ME) of Majero Atoll, bacterial production activities decreased along with the decrease of DOC concentrations (Fig. 3). In the inlet area, DOC concentrations and bacterial production activities were nearly equal to those in the pelagic waters. On the other hand, bacterial production and DAPI-DC at Stn MA during ebb tide (MA2) were as high as in fringing reef water at Ponape, while those during flood tide (MA1 and MA3) were lower. These results can be explained by the fact that pelagic water could easily flow into the inner part with tidal current, as the inner area was wide and deep (ca $30 \mathrm{~m}$ depth), and inlet water of the atoll would be diluted by pelagic waters. At Ponape, however, the fringing reef around the island extends a few kilometers from the island. Therefore, flow of pelagic water over the reef to dilute inner reef water may be limited. Moreover, much run off water could be supplied from the island, resulting in water inside the fringing reef being more eutrophic than in Majero Atoll.

Many previous reports suggested that seasonal and regional fluctuations of bacterial production in the photic zone were controlled by the primary production (Cole et al. 1988), or by the concentration of dissolved organic matter (Kirchman et al. 1986). In this investigation, DOC concentrations and DNA synthesis rates $\left(T_{d} R_{D N A}\right)$ showed a statistically significant positive correlation $\left(\mathrm{r}^{2}=0.67, \mathrm{p}<0.01\right)$ (Figs. $2 \& 3$ ). In the pelagic water, however, protein synthesis activities (Leuprot) were maintained at 3 to $5 \times 10^{-14} \mathrm{~mol} \mathrm{ml}^{-1} \mathrm{~h}^{-1}$, even when DOC concentration and $T d R_{\text {DNA }}$ decreasd (Fig. 4). There was, in other words, no synchronization between protein and DNA syntheses by bacterial assemblages in low nutrient environments. To this phenomenon, several possible explanations can be offered: (1) oligotrophic bacteria could alter their growth rate on the sudden nutrient inflow and transiently enter an unbalanced growth stage; (2) bacteria incapable of growth, but capable of active metabolism of substrates are dominant in pelagic water; (3) oligotrophic bacteria in pelagic water could not incorporate extracellular thymidine for DNA synthesis; or (4) bacteria in pelagic water are different from those in eutrophic areas in regard to their macromolecular biosynthesis or uptake system.

(1) Bacteria are usually considered to be in a balanced growth stage, and then rates of all macromolecular syntheses are proportional to specific growth rates. The moment bacteria encounter new and fresh environments and their growth rates shift (up) to a new stage, synchronization of their macromolecular synthesis is disturbed and they transiently enter unbalanced growing stage (Kirchman et al, 1986). However, in the present study, $5 \mathrm{nM}$ of ${ }^{3} \mathrm{H}$-leucine was added to a final concentration. This leucine concentration would not be high enough to stimulate bacterial growth, because it is almost equivalent to the in situ leucine concentration in pelagic oceans (Lee \& Bada 1977, Eguchi \& Ishida 1990).

(2) There are few studies on the abundance of bacteria which actually take up substrates in natural environments. Results from the autoradiographic technique in eutrophic areas (Fuhrman \& Azam 1982, Tabor \& Neihof 1982) suggested that the number of bacteria which could incorporate thymidine was com- 
parable to those taking up amino acids. In contrast, results on offshore waters of Nova Scotia (Douglas et al. 1987 ) indicated that the numbers of glutamate-incorporating bacteria were greater than those of thymidine-incorporating. These results suggested that the percentage of bacterial assemblage which did not incorporate thymidine, but actively metabolized amino acids, might be higher in the oligotrophic area. Douglas et al. proposed that some bacterial assemblages, living in pelagic ocean of low nutrient for a long time, may be forced to stop reproducing but still retained the ability to metabolize substrates actively. Many starvation experiments using culturable bacteria showed that a considerable proportion of bacteria still maintained respiratory activity, although viable cells decreased significantly after long-term starvation (Amy et al. 1983, Kurath \& Morita 1983). Although growth rates of bacterial assemblages in natural environments are undoubtedly slow, most bacteria cannot be in a dormant stage because of their high secondary production activities (Azam \& Cho 1987).

(3) There is another possibility that most growing bacteria in oligotrophic environments do not take up extracellular thymidine and do not assimilate it into the DNA fraction. Several previous reports pointed out that some bacterial cultures did not utilize extracellular thymidine for DNA synthesis (Ramsey 1974, Johnstone \& Jones 1989, Jeffrey \& Paul 1990). Novitsky (1983) reported in his work using microautoradiography that there were some dividing cells which did not incorporate ${ }^{3} \mathrm{H}$-thymidine in a natural aquatic ecosystem.

(4) In their review, Hirsh et al. (1979) proposed physiological properties of an 'ideal' oligotroph adapting to a low nutrient flux environment. These were: (1) the ideal oligotroph must have substrate uptake mechanisms with high affinity in order to react to low nutrient inflow sensitively and to take it up quickly (Ishida et al. 1982); and (2) the ideal oligotroph spends valuable metabolic energy obtained from limited nutrients for the maintenance of a high affinity uptake system rather than for multiplication (DNA synthesis). In the present study, bacterial assemblages in oligotrophic areas could take up leucine of low concentration effectively even when DNA synthesis was suppressed (Fig. 5A). As the leucine assimilation rates of these bacterial assemblages were larger than the leucine incorporation rates into the protein fraction, about half of the leucine taken up into the cell was promptly utilized for incorporation into the protein fraction (Fig. 5B). This result suggests that bacteria in oligotrophic waters would consume most energy to maintain their efficient uptake systems.

Previous studies reported that nutrient deprivation caused some physiological changes of marine bacterial cells in cell volume, endogenous metabolism protein composition and so on (Novitsky \& Morita 1978,
Geesey \& Morita 1981, Kurath \& Morita 1983, Mårdén et al. 1985, Nyström et al. 1988). A copiotrophic bacterium, S14, which possessed 2 leucine uptake systems of low and high affinities, acitvated the high-affinity system under starved conditions (Mărdén et al. 1987).

In our laboratory studies with strains of obligate oligotrophs and facultative oligotrophs isolated from pelagic water in the Sea of Japan, oligotrophs growing in a low nutrient medium $\left(0.5 \mathrm{mg}\right.$ peptone $\left.\mathrm{l}^{-1}\right)$ maintained relatively high leucine and protein synthesis activity, although DNA synthesis activity was lower, compared with those growing in a high nutrient medium $\left(0.5 \mathrm{~g}\right.$ peptone $\left.\mathrm{l}^{-1}\right)$ (unpubl.). This result suggests that bacterial assemblages in oligotrophic environments mostly consume their energy for the maintenance of uptake system and metabolic activities. It was reported that Escherichia coli cells growing in a carbon-limited chemostat with a low growth rate maintained higher activities of potential protein synthesis than actual synthesis rate and this 'extra' protein synthesis activity had a great selective advantage in fluctuating environments (Koch 1971). These physiological properties of bacterial assemblages in oligotrophic areas may relate to the finding that small bacteria in such areas have a higher percentage of protein content to cell volume than large ones in eutrophic areas (Simon \& Azam 1989).

The present study has clarified that metabolically active oligotrophic bacteria formed the majority of microbial communities in pelagic oceans, and suggested that these bacteria possess special physiological properties different from those of bacteria in eutrophic environments, due to genetical adaptation to a low nutrient flux environment.

Acknowledgments. We thank the scientists, captain, officers and crew of the RV 'Hakuho-maru', University of Tokyo, for their kind assistance in sampling during the $\mathrm{KH}-88-1$ cruise, and Dr Nakanishi and Mr Nakano, Otsu Hydrobiological Station, Kyoto University, for kind help with DOC analysis.

\section{LITERATURE CITED}

Akagi, Y., Taga, N., Simidu, U. (1977). Isolation and distribution of oligotrophic marine bacteria. Can. J. Microbiol. 23: $981-987$

Amy, P. S., Pauling, C., Morita, R. Y (1983). Starvationsurvival processes of a marine vibrio. Appl. environ. Microbiol. 45: 1041-1048

Azam, F., Fuhrman, J. A. (1984). Measurement of bacterioplankton growth in the sea and its regulation by environmental conditions. In: Hobbie, J. E., Williams, P. J. (eds.) Heterotrophic activity in the sea. Plenum Publishing Corp., New York, p. 179-196

Azam, F. Cho, B. (1987). Bacterial utilization of organic matter in the sea. In: Fletcher, M., Gray, T R. G., Jones, J. G. (eds.) Ecology of microbial communities. Cambridge University Press, Cambridge, p. 261-281

Carlucci, A. F., Shimp, S. L. (1976). Distribution, isolation, and culturable characteristics of low-nutrient marine bacteria. 
University of California Institute of Marine Resources, IMR report No. 76-7, p. 827-875

Chin-Leo, G., Kirchman, D. L. (1988). Estimating bacterial production in marine waters from the simultaneous incorporation of thymidine and leucine. Appl. environ. Microbiol. 54: 1934-1939

Cole, J. J., Findlay, S., Pace, M. L. (1988). Bacterial production in fresh and saltwater ecosystems: a cross-system overview. Mar. Ecol. Prog. Ser. 43: 1-10

Douglas, D. J., Novitsky, J. A., Fournier, R. O. (1987). Microautoradiography-based enumeration of bacterial estimates of thymidine-specific growth and production rates. Mar. Ecol. Prog. Ser. 36: 91-99

Ducklow, H. W. Kirchman, D. L. (1983). Bacterial dynamics and distribution during a spring diatom bloom in the Hudson River plume, USA. J. Plankton Res. 5: 333-355

Ducklow, H. W., Purdie, D. A. Williams, LeB P. J., Davis, J. M. (1986). Bacterioplankton: a sink for carbon in a coastal marine plankton community. Science 232: 865-867

Eguchi, M., Ishida, Y (1990). Oligotrophic properties of heterotrophic bacteria and in situ heterotrophic activity in pelagic seawater. FEMS Microbiol. Ecol. 73: 23-30

Fuhrman, J. A., Azam, F. (1982). Thymidine incorporation as a measure of heterotrophic bacterioplankton production in marine surface water; evaluation and field results. Mar. Biol. 66: 109-120

Geesey, G. G., Morita, R. Y. (1981). Relationship of cell envelope stability to substrate capture in a marine psychrophilic bacterium. Appl. environ. Microbiol. 42: 533-540

Hagström, Å., Azam, F., Andersson, A., Wikner, J., Rassoulzadegan, F. (1988). Microbial loop in an oligotrophic pelagic marine ecosystem: possible roles of cyanobacteria and nanoflagellates in the organic fluxes. Mar. Ecol. Prog. Ser. 49: 171-178

Hirsh, P., Bernhard, M., Cohen, S. S., Ensign, J. C., Jannasch, H. W., Koch, A. L., Marshall, K. C., Matin, A., Poindexter, J. S., Rittenberg, S. C., Smith, D. C., Veldkamp, H. (1979). Life under conditions of low nutrient concentrations. In: Shilo, M. (ed.) Strategies of microbial life in extreme environments. Dahlem Konferenzen Life Science Research Report 13, Verlag Chemie, Weinheim, p. 357-372

Ishida, Y., Equchi, M., Kadota, H. (1986). Existence of obligately oligotrophic bacteria as a dominant population in the South China Sea and the West Pacific Ocean. Mar Ecol. Prog. Ser 30: 197-203

Ishida, Y., Imai, I., Miyagaki, T., Kadota, H. (1982). Growth and uptake kinetics of a facultatively oligotrophic bacterium at low nutrient concentrations. Microb. Ecol. 8: 23-32

Ishida, Y., Kadota, H. (1979). A new method for enumeration of oligotrophic bacteria in lake water. Arch. Hydrobiol Beih. Ergebn. Limnol. 12: 77-85

Ishida, Y., Shibahara, K., Uchida, H., Kadota, H. (1980). Distribution of obligately oligotrophic bacteria in Lake Biwa. Bull. Jap. Soc. scient. Fish. 46: 1151-1158

Johnstone, B. H. Jones, R. D. (1989). A study on the Iack of [methyl- ${ }^{3} \mathrm{H}$ ] thymidine uptake and incorporation by chemolithotrophic bacteria. Microb. Ecol. 18: 73-77

Jeffrey, W. H., Paul, J. H. (1990). Thymidine uptake, thymidine incorporation, and thymidine kinase activity in marine bacterium isolates. Appl. environ. Microbiol. 45: 1367-1372

Kirchman, D., Hoch, M. P. (1988). Bacterial production in the Delaware Bay estuary estimated from thymidine and leucine incorporation rates. Mar. Ecol. Prog. Ser. 45: 169-178

Kirchman, D., K'nees, E., Hodson, R. (1985). Leucine incorpo- ration and its potential as a measure of protein synthesis by bacteria in natural aquatic systems. Appl. environ. Microbiol. 49: 599-607

Kirchman, D., Murray, R. E., Hodson, R. E. (1986). Rates of DNA and protein synthesis by heterotrophic bacteria in aquatic environment: a comparison between the thymidine and leucine approaches. In: Megysar, F., Ganter, M. (eds.) Proc. Fourth International Symposium of Microbial Ecology. Sbvene Society for Microbiology, Ljubljana, Yugoslavia, p. 631-637

Kirchman, D., Soto, Y., Wambeck, F. V., Bianchi, M. (1989). Bacterial production in the Rhone River plume: effect of mixing on relationships among microbial assemblages. Mar. Ecol. Prog. Ser. 53: 267-275

Koch, A. L. (1971). The adaptive responses of Escherichia coli to a feast and famine existence. Adv, microb. Physiol. 6: $147-217$

Kurath, G., Morita, R. Y. (1983). Starvation-survival physiological studies of a marine Pseudomonas sp. Appl. environ. Microbiol. 45: 1206-1211

Lee, C., Bada, J. L. (1977). Dissolved amino acids in the equatorial Pacific, the Sargasso Sea and Biscayne Bay. Limnol. Oceanogr. 22: 502-510

Mårdén, P., Nyström, T., Kjelleberg, S. (1987). Uptake of Ieucine by a marine Gram-negative heterotrophic bacterium during exposure to starvation conditions. FEMS Microbiol. Ecol. 45: 233-241

Mårdén, P., Tunlid, A., Malmcrona-Friberg, K., Odham, G. Kjelleberg, S. (198). Physiological and morphological changes during short term starvation of marine bacterial isolates. Arch. Microbiol. 142: 326-332

Morita, R. Y (1985). Starvation and miniaturization of heterotrophs, with special emphasis on maintenance of the starved viable stat. In: Fletcher, M., Floodgate, G. D. (eds.) Bacteria in their natural environments. Academic Press, New York, p. 111-130

Novitsky, J. A. (1983). Heterotrophic activity throughout a vertical profile of seawater and sediment in Halifax Harbor, Canada. Appl. environ. Microbiol. 45: 1753-1760

Novitsky, J. A. Morita, R. Y (1978). Possible strategy for the survival of marine bacteria under starvation conditions Mar. Biol. 48: 289-295

Nyström, T., Albertson, N., Kjelleberg, S. (1988). Synthesis of membrane and periplasmic proteins during starvation of a marine Vibrio sp. J. gen. Microbiol. 134: 1645-1651

Porter, K. G., Feig, Y S. (1980). The use of DAPI for identifying and counting aquatic microflora. Limnol. Oceanogr. 25 $943-948$

Ramsay, A. J. (1974). The use of autoradiography to determine the proportion of bacteria metabolizing in an aquatic environment. J. gen. Microbiol. 80: 363-373

Rosenberg, R., Dahl, E., Edler, L., Fyrberg, L., Graneli, E., Graneri, W., Hagström, \&., Lindahi, O., Matos, M. O., Pettersson, K., Sahlsten, E., Tiselius, P., Turk, V., Wikner, J. (1990). Pelagic nutrient and energy transfer during spring in the open and coastal Skagerrak. Mar. Ecol. Prog. Ser. $61 \cdot 215-231$

Simon, M., Azam, F (1989). Protein content and protein synthesis rates of planktonic marine bacteria. Mar. Ecol. Prog. Ser. 51. 201-213

Tabor, P. S., Neihof, R. A. (1982). Improved microautoradiographic method to determine individual microorganisms active in substrate uptake in natural waters. Appl environ. Microbiol. 44: 945-953

Manuscript first received: November 14, 1990

Revised version accepted: July 3, 1991 